\title{
PENGARUH LAMA FERMENTASI TERHADAP KANDUNGAN PROTEIN SUSU KEFIR SEBAGAI BAHAN PENYUSUN PETUNJUK PRAKTIKUM MATA KULIAH BIOKIMIA
}

\author{
Susanti $^{1}$, Sri Utami ${ }^{2}$ \\ ${ }^{1,2)}$ Program Studi Pendidikan Biologi FPMIPA IKIP PGRI Madiun \\ sriutami31@yahoo.co.id
}

\begin{abstract}
Highly content of nutrition in milk a perfect for microba to grow. Microba can pollute the milk fastly so it can not be consume. Fermentation is one way to avoid the milk decay. Fermentation of milk is conducted by inoculating pasteurized milk with kefir grains additional as cultur starter. The objective of this research is knowing the effect of fermentation period toward protein content of kefir milk as material to compile guideline book for lab work in biochemistry class. The research is quantitative with RAL factorial $4 x 1$ in 3 times repetition. The factors of research are fermentation in 0 hour (t1), 12 hours ( $t 2), 24$ hours ( $t 3), 36$ hours ( $t 4)$. Research use titration formol to collect the data of protein content. Anava one tail is used to examine the hypothesis continued with BNT examination. The result of hypothesis shows that sig $t$ (fermentation period) for protein content in kefir milk 0,000 with significance degree is 0,05. It shown that sig $t<0,05$. From the result above, the conclusion is fermentation period affect the protein content in kefir milk.
\end{abstract}

Keywords : kefir milk, fermentation period, protein, guideline book

\section{PENDAHULUAN}

Konsumsi susu sapi segar di Indonesia semakin meningkat. Susu sapi segar mengandung zat-zat makanan yang yang diperlukan oleh tubuh seperti protein, lemak, karbohidrat, mineral dan vitamin. Susu merupakan sumber protein hewani yang memiliki peran penting dalam kesehatan, karena komponen gizi yang komplek (Miskiyah, 2009). Protein merupakan salah satu kandungan dalam susu segar yang dibutuhkan oleh tubuh manusia (Winarno dan Ivone, 2007). Protein mempunyai fungsi penting dalam proses pembentukan jaringan tubuh manusia yaitu dengan mensintesisnya dari makanan yang dikonsumsi. Jaringanjaringan tubuh vital manusia yang pembentukannya sangat tergantung pada tersedianya protein antara lain enzim, hormon dan antibodi (Universitas Indonesia, 2011).

Kandungan gizi yang tinggi pada susu merupakan media yang sangat sesuai dan disukai oleh mikroba untuk tumbuh dan berkembang. Mikroba dapat mencemari susu dalam waktu singkat sehingga susu dapat menjadi tidak layak konsumsi bila tidak ditangani dengan benar (Saleh, dalam Miskiyah, 2009). Fermentasi adalah salah satu cara untuk menghindari kerusakan susu sapi. Susu difermentasi dengan cara menginokulasi susu yang telah dipasteurisasi dengan suatu mikroorganisme yang diketahui sebagai biakan pemula (starter cultur). Salah satu sumber mikroorganisme yang dapat digunakan sebagai starter cultur dalam proses fermentasi adalah kefir grains. Bakteri asam laktat seperti Lactobacillus lactis, Lactobacillus delbrueckii subsp. bersama ragi terdapat dalam kefir grains dan menghasilkan asam dan alkohol. Berdasarkan penelitian yang dilakukan oleh Ot'es dan Cagindi (2003) waktu fermentasi susu segar dengan kefir grains dilakukan selama 18-24 jam dengan kandungan protein dalam susu kefir sebesar 3,3\%.

Susu sapi segar adalah susu yang kandungan alaminya belum berubah dan belum mengalami proses pengolahan apapun yang memiliki kandungan gizi yang 
tinggi karena dalam susu sapi segar mengandung zat-zat makanan yang lengkap dan seimbang (Miskiyah, 2009). Komposisi susu secara umum adalah 87,2 \% air, 3,7 \% lemak susu, 3,5\% protein, 4,9\% lactose dan $0,7 \%$ abu. Komposisi bervariasi tergantung pada makanan, jenis sapi, suplemen sapi dan tempat hidupnya (Prasetya, 2012).

Nutrien yang juga terkandung dalam susu sapi yaitu vitamin D dan K yang baik untuk kesehatan tulang bahkan untuk pembentukan gigi, iodium merupakan mineral penting untuk fungsi tiroid, vitamin B12 dan riboflavin yang diperlukan untuk produksi energi dan kesehatan kardiovaskular, biotin, vitamin A, potasium, magnesium, selenium, thiamin dan asam linoat. Protein yang terdapat dalam susu terdiri dari kasein dan protein serum atau whey protein. Protein susu memiliki mutu dan gizi yang sepadan dengan daging dan hanya diungguli oleh protein telur (Winarno dan Ivone, 2007). Kasein di dalam susu sapi dikenal sebagai senyawa posfoprotein yang dapat diendapkan dengan pengasaman. Cairan yang tersisa dari pengendapan kasein disebut dengan whey protein.

Fratiwi et al. (2008) menjelaskan fermentasi adalah proses yang menghasilkan berbagai produk baik secara aerob maupun anaerob dengan melibatkan aktivitas mikroba yang berperan sebagai starter cultur. Fermentasi dapat menambah keanekaragaman pangan dan menghasilkan produk dengan cita rasa, aroma, serta tekstur yang khas, selain itu proses fermentasi juga dapat memperpanjang masa simpan produk. Proses fermentasi menghasilkan senyawa-senyawa yang sangat berguna bagi kesehatan. Secara biokimia, fermentasi diartikan sebagai proses pembentukan energi dimana senyawa organik berperan sebagai pendonor elektron terminal. Secara alamiah susu telah ditumbuhi oleh Lactobacillus dan Streptococcus, dua mikroba tersebut pada suhu ruangan akan mengubah susu menjadi asam. Fermentasi secara spontan ini akan mengumpulkan susu dan mencegah proses pembusukan susu. Dasar fermentasi susu adalah fermentasi komponen gula di dalam susu terutama laktosa menjadi asam laktat dan asam-asam lain. Fermentasi susu dapat menghambat pertumbuhan mikroba patogen dan mikroba perusak susu, sehingga masa simpan susu dapat diperpanjang. Karno (2004) menjelaskan bahwa susu difermentasi dengan cara menginokulasi susu yang telah dipasteurisasi dengan suatu biakan mikroorganisme sebagai biakan pemula (starter cultur) sehingga dihasilkan produk olahan susu yang diinginkan.

Kefir grains atau biasa disebut dengan biji kefir merupakan starter cultur yang digunakan dalam pembuatan susu kefir. Biji kefir bukanlah biji yang dihasilkan oleh buah, tetapi biji kefir adalah kumpulan dari bakteri asam laktat, khamir dan gula polisakarida. Kefir grains terlihat seperti potongan - potongan koral atau kumpulan kecil bunga kol, yang berisi campuran kompleks bacteri termasuk berbagai jenis dari lactobacilli, lactococci, leucocostocs dan acetobakteria (Ot'es dan Cagindi, 2003). Biji kefir berukuran mulai dari biji gandum sampai biji kenari dan terus berkembang atau bertambah besar selama masa inkubasi. Spesies mikroorganisme dalam biji kefir diantaranya Lactococcus lactis, Lactobacillus acidophilus, Lb. kefir, Lb. kefirgranum, $L b$. parakefir yang berfungsi dalam pembentukan asam laktat dari laktosa. Lactobacillus kefir ranofaciens sebagai pembentuk lendir (matriks butiran kefir). Leunostoc sp. membentuk diasetil dari sitrat. Candida kefir pembentuk etanol dan karbondioksida dari laktosa. Selain itu dalam biji kefir juga ditemukan Lactobacillus brevis dan khamir (Torulopis holmii dan Saccharomyces delbrueckii). Namun menurut Farnworth dalam Purnomo dan Muslimin (2012) kefir yang berasal dari tempat yang berbeda, kandungan organisme didalamnya juga memiliki perbedaan. Bakteri homofermentatif asam 
laktat dalam biji kefir terutama akan menghasilkan asam laktat dari fermentasi lactosa. Bakteri heterofermentatif asam laktat akan menghasilkan asam laktat dan $\mathrm{CO}_{2}$ dari lactosa.

Susu kefir adalah produk fermentasi susu dengan menggunakan biji kefir sebagai starter culture. Susu kefir beraroma asam, alkoholik dan karbonat. Menurut penelitian yang dilakukan oleh balai besar penelitian dan pengembangan pascapanen pertanian (2007) “ Kadar asam laktat kefir berkisar 0,8-1,1\%, alkohol 0,5-2,5\%, sedikit gas karbon dioksida, kelompok vitamin B serta diasetil dan asetaldehid. Komposisi dan kadar nutrisi kefir adalah air $89,5 \%$, lemak $1,5 \%$, protein $3,5 \%$, abu $0,6 \%$, laktosa $4,5 \%$ dengan nilai $\mathrm{pH} 4,6$ ". Pembuatan susu kefir diawali dengan melakukan pasteurisasi pada susu segar dengan pemanasan $72^{\circ} \mathrm{C}$ dalam 5 detik (Miskiyah, 2009). Kemudian didinginkan sampai suhu $20-25{ }^{0} \mathrm{C}$ dan ditambahkan biji kefir $5 \%$ ke dalam susu yang telah dingin (Ot'es dan Cagindi, 2003). Winarno dan Ivone (2007) biji kefir yang ditambahkan dalam 1 liter susu adalah 50 60 gram. Fermentasi susu dengan kefir grains dilakukan selama 18, 21 dan 24 jam dalam suhu $24^{0} \mathrm{C}$. Setelah masa pemeraman, granula dipisahkan dari susu dengan saringan dan susu kefir dimasukkan dalam botol. Susu kefir disimpan dalam suhu $4^{0} \mathrm{C}$ sebelum dikonsumsi (Chen et al, 2006).

Petunjuk praktikum adalah ketentuan yang memberi arah maupun bimbingan bagaimana sesuatu harus dilakukan sehingga bagian dari pengajaran yang bertujuan agar peserta didik mendapat kesempatan menguji teori yang sudah diperoleh dengan maksimal. Petunjuk praktikum uji kandungan protein adalah pedoman yang disusun untuk digunakan oleh mahasiswa selama menjalankan praktikum biokimia materi uji kandungan protein dalam bahan pangan. Penelitian perlu dilakukan untuk mengetahui adanya pengaruh lama fermentasi terhadap kandungan protein susu kefir dan menyusun sebagian hasil penelitian pengaruh lama fermentasi terhadap kandungan protein susu kefir untuk bahan penyusun petunjuk praktikum mata kuliah biokimia.

\section{METODE}

Penelitian dilakukan di laboratorium Pendidikan Biologi IKIP PGRI Madiun. Rancangan percobaan yang digunakan adalah RAL (Rancangan Acak Lengkap) faktorial dengan 3 kali ulangan. Penelitian menggunakan faktorial $4 \times 1$, artinya hanya ada satu faktor percobaan, yaitu $\mathrm{T}_{1}, \mathrm{~T}_{2}, \mathrm{~T}_{3}$ dan $\mathrm{T}_{4}$ kemudian menghasilkan 4 kombinasi perlakuan. Faktor percobaan tersebut adalah perlakuan berupa lama fermentasi yang terdiri atas waktu fermentasi selama 12 jam, 24 jam dan 36 jam. Teknik pengumpulan data adalah cara yang digunakan untuk memperoleh data penelitian. Teknik pengumpulan data yang digunakan untuk mengetahui kadar protein pada sampel dengan menggunakan titrasi formol. Susu sapi yang telah mengalami fermentasi selama 12 jam, 24 jam dan 36 jam serta kontrol, masing - masing diambil 10 gr. Rumus yang digunakan untuk menghitung prosentase protein adalah.

$\%$ protein susu $=1,83 \times \mathrm{ml}$ titrasi formol

Alat yang digunakan adalah 1 buah panci berukuran diameter $16 \mathrm{~cm}, 12$ buah toples plastik bervolume $250 \mathrm{ml}, 1$ buah saringan stainless berdiameter $12 \mathrm{~cm}, 1$ buah neraca analitik, 1 buah gelas ukur dengan volume $250 \mathrm{ml}, 1$ buah pengaduk, 1 buah erlenmeyer dengan volume $50 \mathrm{ml}, 1$ buah pipet ukur dengan volume $20 \mathrm{ml}, 1$ buah Pipet volumetrik ukuran $10 \mathrm{ml}, 1$ buah buret merk pyrex.

Bahan yang digunakan adalah Susu sapi segar sebanyak 3 L, Kefir grains 150 gram, K-oksalat jenuh $50 \mathrm{ml}, \mathrm{NaOH} 0,1 \mathrm{~N}$ $50 \mathrm{ml}$, warna standar (larutan contoh + air + K-oksalat jenuh + Resinulin- $\mathrm{HCl}$ ), formadehida $40 \% 50 \mathrm{ml}$, air suling 1 liter. Bahan uji penelitian berupa 12 botol yang 
yang telah diberi label sesuai dengan waktu fermentasi yaitu 3 botol sebagai kontrol (tidak dilakukan proses fermentasi), 3 botol untuk fermentasi selama 12 jam, 3 botol untuk fermentasi 24 jam dan 3 botol untuk fermentasi 36 jam. Masing-masing botol berisi $200 \mathrm{ml}$ susu sapi yang telah dipasteurisasi dan ditambahkan 10 gram kefir grains, kecuali 3 botol kontrol.

Prosedur Penelitian adalah menyiapkan 12 botol plastik yang telah disterilkan. Masing-masing botol telah diberi label sesuai dengan perlakuan. Susu sapi segar sebanyak 6 liter dilakukan pasteurisasi dalam suhu $72^{\circ} \mathrm{C}$ selama 5 detik (Miskiyah, 2009:2). Masing-masing botol plastik dimasukkan kefir grains sebagai stater sebanyak 5\% (Ot'es dan Cagindi, 2003). Bibit kefir yang dimasukkan dalam masing-masing botol sebanyak 10 gram (Winarno dan Ivone, 2007). Susu sapi yang telah mengalami pasteurisasi kemudian dimasukkan ke dalam masing-masing botol sebanyak 200 ml. Pemeraman dilakukan sesuai dengan label yang tertera pada botol, yaitu selama 12 jam, 24 jam dan 36 jam.

Setelah waktu fermentasi telah berlangsung selama waktu yang telah ditentukan pada masing- masing botol susu kefir siap dipanen. Tiap botol diambil $10 \mathrm{ml}$ liter susu kefir untuk dilakukan pengujian kadar proteinnya. Proses pengambilan data dilakukan dengan teknik titrasi formol untuk mengetahui kadar protein dalam susu kefir.

Data kadar protein susu kefir yang diperoleh dalam bentuk prosentase kemudian dianalisis secara statistik. Data dianalisis dengan Anava satu jalan, jika hasil uji hipotesis signifikan (probabilitas $($ Sig) < 0,05) maka dilanjutkan dengan uji lanjutan, yaitu BNT (Beda Nyata Terkecil). Analisis data untuk anava dua jalan dan BNT menggunakan SPSS Versi 17.

\section{HASIL DAN PEMBAHASAN}

Data prosentase protein yang didapatkan dengan metode titrasi formol dapat dilihat pada tabel 1 .

Tabel 1. Data Prosentase Protein Susu Kefir

\begin{tabular}{cccl}
\hline \multicolumn{4}{c}{ Perlakuan Fermentasi } \\
\hline Kontrol & 12 Jam & 24 jam & 36 jam \\
\hline 4,9410 & 16,8360 & 22,6920 & 18,6660 \\
4,2090 & 15,3720 & 23,9730 & 18,4830 \\
4,3920 & 16,1040 & 22,6920 & 18,6660 \\
\hline
\end{tabular}

Tabel 1 menunjukkan adanya perbedaan prosentase kandungan protein pada setiap perlakuan. Prosentase kandungan protein tertinggi adalah pada perlakuan lama fermentasi selama 24 jam sebesar $23,9730 \%$, sedangkan prosentase kandungan protein terendah adalah pada susu sapi yang tidak mengalami proses fermentasi sebesar 4,2090\%. Hasil pengujian hipotesis dengan menggunakan analisis varian satu jalan menunjukkan bahwa lama fermentasi berpengaruh nyata terhadap kandungan protein susu kefir. Susu sapi yang difermentasi dengan kefir grains selama 24 jam menunjukkan kadar protein yang paling tinggi, hasil penelitian sesuai dengan yang dilakukan Motaghi et al. (1997) bahwa susu kefir yang difermentasi selama 24 jam adalah susu kefir yang terbaik.

Susu sapi yang tidak difermentasi menggunakan kefir grains memiliki kandungan protein paling rendah dan meningkat pada susu sapi yang telah diberi kefir grains dan difermentasi selama 12 jam dan mencapai titik maksimum pada 24 jam. Kandungan protein susu sapi lebih rendah dibandingkan kandungan susu kefir karena dalam kefir grains mengandung 40$60 \%$ protein (Sawitri, 2012), sehingga penambahan kefir grains meningkatkan kadar protein. Yusmarini dan Efendi dalam Sawitri (2011) protein yang terkandung dalam susu fermentasi merupakan jumlah total dari protein susu dan protein bakteribakteri yang terkandung di dalamnya. Fermentasi 12 jam kandungan protein lebih 
rendah dibandingkan dengan fermentasi 24 jam, karena pada fermentasi 12 jam bakteri dan khamir sedang pada fase adaptasi sehingga pertumbuhan bakteri belum maksimal dan mengakibatkan jumlah bakteri yang terdapat dalam susu fermentasi 12 jam lebih rendah. Menurut Rattray dan O'Connell (2011) bahwa protein pada susu kefir belum jelas apakah yang menghasilkan aktifitas khamir atau bakteri asam laktat.

Hasil penelitian menunjukkan bahwa kadar protein menurun pada susu kefir yang difermentasi selama 36 jam. Jumlah bakteri asam laktat dan khamir akan terus bertambah selama fermentasi berlangsung. Peningkatan jumlah bakteri asam laktat menyebabkan meningkatnya metabolisme bakteri asam laktat yang membutuhkan lebih banyak bahan baku untuk dimetabolisme. Bahan baku yang dibutuhkan bakteri asam laktat untuk dimetabolisme adalah laktosa dan kasein. Laktosa dan kasein dimetabolisme oleh bakteri asam laktat menjadi asam laktat, asam asetat, diasetil dan alkohol (Sawitri, 2012). Haryadi (2012) menjelaskan bahwa protein susu disusun oleh beberapa protein spesifik yaitu kasein dan whey protein, dengan kadar kasein $80 \%$ dan sisanya whey protein. Karena kasein adalah salah satu komponen penyusun protein susu maka bertambahnya jumlah kasein yang digunakan untuk proses metabolisme oleh bakteri asam laktat mengakibatkan jumlah protein yang terkandung pada susu kefir menurun.

Protein akan terdenaturasi oleh panas atau perubahan $\mathrm{pH}$ (Fried dan Hademenos, 2005). Seperti hasil penelitian Motaghi et al (1997) bahwa susu kefir yang difermentasi selama 24 jam memiliki pH 3,89 dan susu kefir yang difermentasi selama 36 jam memiliki $\mathrm{pH} 3,01$. Nilai $\mathrm{pH}$ yang menurun pada fermentasi selama 36 jam menyebabkan protein pada susu kefir menurun. Menurunnya nilai $\mathrm{pH}$ karena jumlah asam laktat yang dihasilkan bakteri asam laktat semakin banyak dan terakumulasi didalam susu yang difermentasi sehingga menyebabkan nilai $\mathrm{pH}$ menurun.

Hasil penelitian pengaruh lama fermentasi terhadap kandungan protein susu kefir dapat dijadikan sebagai bahan penyusunan petunjuk praktikum mata kuliah biokimia pada KD. Memahami pengertian Protein, manfaat dan metabolismenya di dalam tubuh manusia. Petunjuk praktikum yang dihasilkan dapat digunakan dalam kegiatan praktikum untuk mengetahui kandungan protein pada kandungan makanan salah satunya susu kefir. Aspek-aspek yang dapat dinilai dari kegiatan praktikum meliputi aspek spikomotorik yang didapat dari kecakapan mahasiswa saat kegiatan praktikum berlangsung, aspek afektif yang didapat dari sikap dan kesiapan mahasiswa sebelum dan saat praktikum dan aspek kognitif yang didapat dari laporan hasil praktikum yang disusun setelah kegiatan praktikum dilaksanakan. Format petunjuk praktikum meliputi tujuan yang ingin dicapai, dasar teori, alat dan bahan yang digunakan dalama praktikum, prosedur/cara kerja dalam praktikum dan tabel hasil praktikum.

\section{SIMPULAN}

Berdasarkan hasil analisa data menunjukkan bahwa lama fermentasi berpengaruh nyata terhadap kandungan protein susu kefir. Susu sapi yang difermentasi dengan kefir grains sebagai starter cultur selama 24 jam memiliki kadar protein tertinggi. Sebagian hasil penelitian pengaruh lama fermentasi terhadap kandungan protein susu kefir dapat digunakan sebagai bahan penyusun petunjuk praktikum biokimia pada KD. Memahami pengertian Protein, manfaat dan metabolismenya di dalam tubuh manusia. 


\section{DAFTAR PUSTAKA}

Balai Besar Penelitian dan Pengembangan Pascapanen Pertanian. 2007. Kefir, Susu Fermentasi dengan Rasa Menyegarkan. Warta Penelitian dan Pengembangan Pertanian (Online), Vol 29, No.2,

Chen, M. J., Liu1, J. R., Sheu, J. F., Lin, C. W. dan Chuang, C. L. 2006. Study on Skin Care Properties of Milk Kefir Whey. Asian-Aust. J. Anim. Sci (Online), Vol 19, No. 6.

Departemen gizi dan kesehatan masyarakat. 2011. Gizi dan Kesehatan Masyarakat. Jakarta: Fakultas Kesehatan Masyarakat Universitas Indonesia.

Winarno F.G. dan Ivone E. F. 2007. Susu dan Produk Fermentasi. Bogor: M-Brio Press.

Fratiwi, Yulneriwarni dan Noverita. 2008. Fermentasi Kefir dari Susu Kacang-Kacangan. VIS VITALIS (Online), Vol. 01, No. 2.

Fried, George $\mathrm{H}$ dan Hademenos, George J. 2005. Biologi. Jakarta: Erlangga.

Prasetya H. 2012. Prospek Cerah Beternak Sapi Perah. Sleman Yogyakarta: Pustaka Baru Press.

Karno. 2004. Buku Pegangan Kuliah Mikrobiologi. Madiun: IKIP PGRI Madiun.

Sawitri M.E. 2011. Kajian Penggunaan Eksrak Susu Kedelai Terhadap Kualitas Kefir Susu Kambing. Jurnal Ternak Tropika. Vol. 12, (1)

Sawitri M.E. 2012. Kajian konsentrasi kefir grain dan lama simpan dalam refrigerator terhadap kualitas kimiawi kefir rendah lemak. Jurnal Ilmu-ilmu Peternakan (Online), Vol 21, No. 1.

Miskiyah. 2011. Kajian Standar Nasional Indonesia Susu Cair di indonesia. Jurnal Standardisasi (Online), Vol. 13 No. 1.
Motaghi M., Mazaheri M., Maozami N., Farkhondeh A., Fooladi M.H dan Goltapeh E.M. 1997. Short Communication: Kefir Production in Iran. Word Journal of Microbiology \& Biotechnology

Ot'es, Semih. and Cagindi, Oz'em., 2003. Kefir: A Probiotic DairyComposition, Nutritional and Therapeutic Aspects. Pakistan Journal of Nutrition (Online), vol. 2, No. 2. 